\title{
Nuoret ikäluokat Suomessa ja Yhdysvalloissa
}

Professori FRANK L. SWEETSER *, Boston University ja

valtiot.tri PAAVO PIEPPONEN, Väestöpoliittinen Tutkimuslaitos

Toisen maailmansodan jälkeen nousi syntyneiden lukumäärä monissa maissa ennätyskorkeuteen. Näin tapahtui sekä Suomessa että Yhdysvalloissa. Tämän tutkielman tarkoituksena on näiden maiden väestötilastojen avulla valaista nuorten ikäluokkien osuutta väestöstä, toisen maailmansodan jälkeisiä suuria ikäluokkia, etsiä demografisen kehityksen syitä ja seurauksia sekä todeta yhteisiä ja erottavia piirteitä maiden kesken.

\section{Nuoret ikäluokat 1920-1960}

Suomi

Alle 5-vuotiaiden osuus koko väestöstä väheni tarkastelukaudella aina vuoteen 1950 asti, jolloin nuorimman ikäryhmän osuus kohosi $12.5 \%$ :iin. Kymmenen vuotta myöhemmin ikäluokan osuus oli alentunut samalle tasolle kuin v. 1940. Vuoden 1950 korkea osuus edusti toisen maailmansodan jälkeen tapahtunutta syntyvyyden lisäystä. 5-9-vuotiaiden osuus väheni vuoteen 1940 asti, minkä jälkeen on tapahtunut jatkuvaa nousua. Näiden nuorimpien ikäluokkien, alle 10-vuotiaiden pienimmät osuudet v. 1940 osoittavat 1930-luvun alhaista syntyvyyttä. Ikäluokkien 10—14 ja 15-19 osuudet alenivat aina 1950-luvulle asti, jolloin ne olivat alimmillaan. V. 1950 olivat 1930-luvulla syntyneet juuri näissä ikäluokissa. 20-24vuotiaiden osuus on vähentynyt vuodesta 1930 lähtien niin että v. 1960 tämä ikäluokka käsitti ainoastaan $7 \%$. 25-29-vuotiaiden osuus tarkastelukaudella nousi vuoteen 1940 asti, minkä jälkeen se on pudonnut ja tarkastelukauden alin suhdeluku, $6.5 \%$, oli v. 1960.

Nuorten ikäluokkien yhteinen osuus koko väestöstä on tarkastelukaudella alentunut $59.8 \%$ :sta $52.1 \%$ :iin eli lähes kahdeksalla prosenttiyksiköllä. Tämä kuvastaa demografista vanhentumista.

* Professori Sweetser oli Fulbright-stipendiaattina Helsingin yliopistossa lukuvuonna $1962-63$. 
T a ulu 1. Nuorten ikäluokkien osuus koko väestöstä 1920-1960.

Ta ble 1. Percent of Total Population by Age, 1920-1960.

\begin{tabular}{lrrrrr}
\hline \multicolumn{5}{l}{ Ikä } & \multicolumn{5}{c}{ Suomi - Finland } \\
Age & 1920 & 1930 & 1940 & 1950 & 1960 \\
\hline $0-4$ & 10.6 & 10.0 & 9.1 & 12.5 & 9.2 \\
$5-9$ & 11.3 & 10.2 & 8.6 & 9.4 & 9.9 \\
$10-14$ & 11.5 & 9.2 & 9.2 & 8.2 & 11.1 \\
$15-19$ & 10.2 & 10.0 & 9.4 & 7.7 & 8.4 \\
$20-24$ & 8.8 & 10.0 & 8.3 & 8.1 & 7.0 \\
$25-29$ & 7.4 & 8.5 & 8.7 & 7.6 & 6.5 \\
$0-29$ & 59.8 & 57.9 & 53.3 & 53.5 & 52.1 \\
& & & & & \\
Ikä & & & & & \\
Age & 1920 & 1930 & 1940 & 1950 & 1960 \\
\hline $0-4$ & 11.0 & 9.3 & 8.0 & 10.7 & 11.3 \\
$5-9$ & 10.8 & 10.3 & 8.1 & 8.8 & 10.4 \\
$10-14$ & 10.1 & 9.8 & 8.9 & 7.4 & 9.4 \\
$15-19$ & 8.9 & 9.4 & 9.4 & 7.1 & 7.4 \\
$20-24$ & 8.8 & 8.9 & 8.8 & 7.6 & 6.1 \\
$25-29$ & 8.6 & 8.0 & 8.4 & 8.1 & 50.6 \\
$0-29$ & 58.2 & 55.7 & 51.6 & 49.7 & \\
\hline
\end{tabular}

Yhdysvallat

Nuorimpien ikäluokkien, 0-4-vuotiaiden, osuus on vuodesta 1920 alentunut vuoteen 1940 saakka, minkä jälkeen se kohosi saavuttaen vuonna 1960 tarkastelukauden ennätyksen, $11.3 \%$. Samanlainen kehitys on tapahtunut 5-9-vuotiaiden ikäluokassa kuitenkin sillä erotuksella, että osuus v. 1960 ei ulottunut vuoden 1920 tasolle. 10-14-vuotiaiden luokka aleni aina vuoteen 1950 asti, jolloin se oli $7.4 \%$, mutta kohosi v. 1960 jo $9.4 \%$ :iin. Ikäluokkien 15-19 osuus oli suurimmillaan vuosina $1930 \mathrm{ja}$ 1940 ja pienimmillään 1950 , jolloin se oli $7.1 \%$. Ikäluokkien $20-24$ ja 25-29 suhdeluvut olivat alimmillaan tarkastelukaudella v. 1960. Kuitenkin näihin ikäluokkiin kuuluvat isät ja äidit nostivat alle 5-vuotiaiden osuuden ennätyskorkeuteen v. 1960. Nämä ikäluokat ovat «pula-ajan lapsia«, 1930-luvulla syntyneitä. Taulusta 1 havaitaan, että ne vuosina 1940, 1950 ja 1960 ovat kaksi pienintä ikäkohorttia.

Myös Yhdysvalloissa on alle 30 -vuotiaiden osuus koko väestöstä alentunut lähes kahdeksalla prosenttiyksiköllä.

Yhteisenä pääpiirteenä molempien maiden demografisessa kehityksessä voidaan havaita seuraavaa. Syntyvyyden aleneva suunta kummassakin 

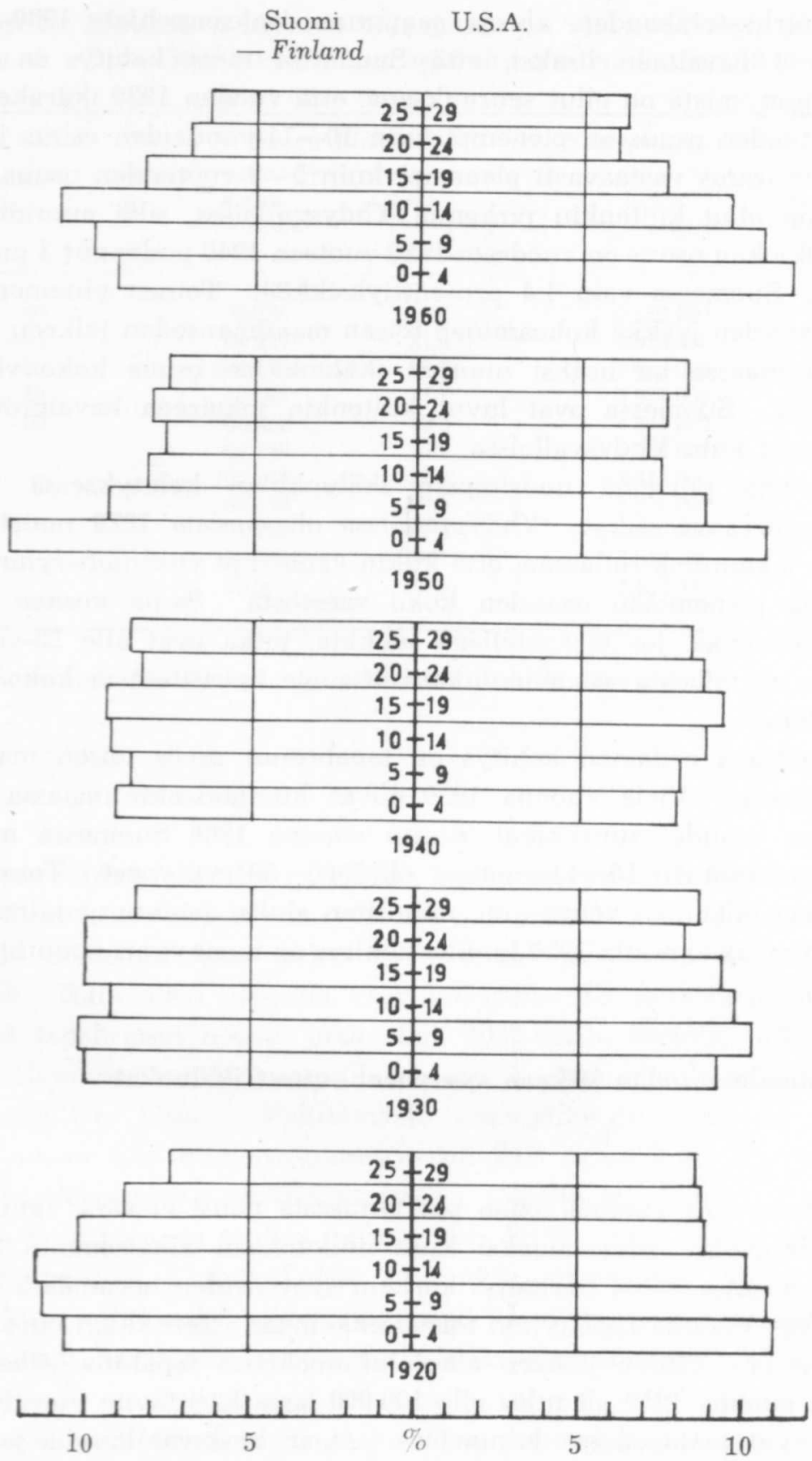

Kuvio 1. Nuorten ikäluokkien prosenttiset osuudet koko väestöstä Suomessa ja Yhdysvalloissa v. 1920-60.

Fig. 1. Youthful Population as Percentage of Total Population, Finland and United States, 1920-60. 
maassa tarkastelukauden alussa saavuttaa laaksonpohjan 1930-luvulla. Kuviosta 1 havaitaan lisäksi, että Suomessa tämä kehitys on alkanut aikaisemmin, mistä on ollut seurauksena, että vuoden 1920 ikärakenteessa 5-9-vuotiaiden osuus on pienempi kuin 10-14-vuotiaiden osuus ja 0 -4vuotiaiden osuus vastaavasti pienempi kuin 5-9-vuotiaiden osuus. Tämä kehitys on ollut kuitenkin jyrkempi Yhdysvalloissa, sillä nuorimman 5vuotisikäluokan osuus on vuodesta 1920 vuoteen 1940 pudonnut 3 prosenttiyksikköä, Suomessa vain 1.4 prosenttiyksikköä. Toinen yhteinen piirre on syntyvyyden jyrkkä kohoaminen toisen maailmansodan jälkeen. Kummassakin maassa on lisäksi nuorten ikäluokkien osuus koko väestöstä vähentynyt. Suomessa ovat luvut kuitenkin jokaisena havaintovuotena korkeammat kuin Yhdysvalloissa.

Erottavina piirteinä nuorimpien ikäluokkien kehityksessä voidaan havaita seuraavat seikat. Yhdysvalloissa oli vuonna 1920 nuorten ikäluokkien jakautuma sellainen, että kukin vanhempi viisivuotisryhmä muodosti aina pienemmän osuuden koko väestöstä. Sama koskee vuoden 1960 jakautumaa, jos tarkastellaan luokkia, jotka ovat alle 25-vuotiaita. Suomessa ei tällaista säännönmukaisuutta ole havaittavissa koko tarkastelukaudella.

Huomattava erilainen kehitys on tapahtunut myös toisen maailmansodan jälkeen. Vielä vuonna 1950 olivat kummassakin maassa alle 5vuotiaiden osuudet suurimmat, mutta vuonna 1960 Suomessa muodosti suurimman ryhmän $10-14$-vuotiaat eli $1946-50$ syntyneet. Toisen maailmansodan jälkeinen kehitys on ollut siten aluksi samansuuntainen kummassakin maassa, mutta 1950-luvulla kehitys on mennyt eri suuntiin.

\section{Toisen maailmansodan jälkeen syntyneet suuret ikäluokat}

Su omi

Jo seuraavana vuonna sodan päättymisesta nousi elävänä syntyneiden lasten lukumäärä suuremmaksi kuin milloinkaan aikaisemmin Suomen väestöhistoriassa. Sitä edeltänyt korkein syntyneiden lukumäärä oli vuodelta 1909. Vuonna 1947 syntyi toistaiseksi maan väkirikkain vuosiluokka, 108168 lasta. Tämän jälkeen alkoi lukumäärissä tapahtua vähenemistä niin että vuonna 1950 oli tultu alle 100000 lasta käsittäviin vuosiluokkiin.

Kun syntymätapausten lukumäärä jaetaan keskiväkiluvulla ja ilmaistaan promilleina, saadaan yleinen syntyneisyysluku. Jos taulusta 2 tarkastelemme ensin eri viisvuotiskausien syntyneisyyslukuja, toteamme, että syntyvyydessä alkoi nousukausi 1930-luvun lopulla ja kesti 1940-luvun lopulle asti. Paluu sodanedelliselle tasolle, jopa sen alapuolelle tapahtui 1950-luvun loppupuolella. Ennätysvuoden 1947 syntyneisyysluku oli 28.00 promillea. 
Taulu 2. Elävänä syntyneet Suomessa ja Yhdysvalloissa 1936-1960.

T a ble 2. Live Births in Finland and the United States, 1936-1960.

\begin{tabular}{l|cc|cc}
\hline \multirow{2}{*}{$\begin{array}{l}\text { Vuosina } \\
\text { Years }\end{array}$} & \multicolumn{2}{|c|}{ Suomi-Finland } & \multicolumn{2}{c}{ Yhdysvallat-United States } \\
\cline { 2 - 5 } & $\begin{array}{c}\text { Luku } \\
\text { Number }\end{array}$ & $\begin{array}{c}\left.\%^{1}{ }^{1}\right) \\
\text { Per } 1000 \\
\text { Population }\end{array}$ & $\begin{array}{c}\text { Luku } \\
\text { Number }\end{array}$ & $\begin{array}{l}\left.\%^{1}{ }^{1}\right) \\
\text { Per } 1000 \\
\text { Population }\end{array}$ \\
\hline & & & & \\
$1936-40$ & 72384 & 19.8 & 2458000 & 18.9 \\
$1941-45$ & 80511 & 21.6 & 2919000 & 21.7 \\
$1946-50$ & 104716 & 26.8 & 3629000 & 24.8 \\
$1951-55$ & 91565 & 22.1 & 3977000 & 25.1 \\
$1956-60$ & 84482 & 19.3 & 4271000 & 24.7 \\
1945 & 95758 & 25.5 & 2858000 & 20.4 \\
1946 & 106075 & 27.9 & 3411000 & 24.1 \\
1947 & 108168 & 28.0 & 3817000 & 26.6 \\
1948 & 107759 & 27.6 & 3637000 & 24.9 \\
1949 & 103515 & 26.1 & 3649000 & 24.5 \\
1950 & 98065 & 24.5 & 3632000 & 24.1 \\
\hline
\end{tabular}

1) \%:na keskiväkiluvusta - per thousand of mean population

Yhdysvallat*

Yhdysvalloissa olivat suurimmat syntyneisyysluvut kaudella 19511955. Myös 1956-60 syntyneisyysluku 24.7 promillea oli vain 0.1 promilleyksikköä pienempi kuin välittömästi sodan jälkeisenä 5-vuotiskautena 1945-50. Näin ollen yleisellä syntyneisyysluvulla mitattuna hedelmällisyydessä tapahtunut nousu, joka alkoi 1930-luvun lopulla, jolloin syntyneisyys oli ainoastaan 18.9 promillea, saavutti toisen maailmansodan aikana 21.7 promillen tason. Välittömästi sodanjälkeisinä vuosina tapahtui jyrkkä nousu niin että syntyneisyys oli 24.8 promillea. Huippuvuoden 1947 syntyneisyysluku oli 26.6 promillea. Tähän asti kehitys Amerikassa oli sama kuin monissa muissa maissa, mm. Suomessa. 1950-luvulla pysytteli syntyneisyys Yhdysvalloissa kuitenkin suunnilleen yhtä korkealla tasolla kuin välittömästi sodan jälkeisinä vuosina. Kun vuosikeskiarvoja tarkastellaan, havaitaan, että kaudella $1951-55$ syntyneisyysluku 25.1 pro-

* Kaikki Yhdysvaltoja koskevat luvut on korjattu ja käsittävät 48 valtiota. Alaskan ja Hawaijin arvot on vähennetty kokonaisluvuista vuosina 1959-1961. Vuodesta 1951 lähtien USA:n syntyvyystilastot perustuvat $50 \%$ :n näytteen analysointiin. Kaikki Yhdysvaltojen syntyvyys- ja avioliittotilastot, jotka mainitaan tässä artikkelissa, on, mikäli toisin ei ole sanottu, saatu julkaisusta VITAL STATISTICS OF THE UNITED STATES, 1959, Vol. I. Vuosia 1960 ja -61 koskevat syntyneisyysluvut ja syntyneiden lukumäärät arvioitiin 48 valtiota varten tiedoista, jotka ovat julkaisussa STATISTICAL ABSTRACT OF THE UNITED STATES, 1961. 
millea on korkein kaikista viisivuotiskausien luvuista 1920-luvun jälkeen. Siten Yhdysvalloissa toisen maailmansodan jälkeinen korkea syntyneisyys on kestänyt 15 vuotta.

Kuten edellä on havaittu syntyneisyyden kehitys Suomessa ja Yhdysvalloissa on samanlainen 1930-luvun lopulta 1940-luvun lopulle, jopa numeroarvot eri 5-vuotiskausina ovat hyvin paljon samanlaiset. Molemmissa maissa oli korkein syntyneisyys samana vuonna, 1947, jolloin Suomen luku oli 1.4 promilleyksikköä suurempi kuin Amerikan. Taulukosta 2 voidaan havaita edelleen, että Suomen väestö saavutti suhteellisen suuren syntyneisyyden pikemmin kuin Yhdysvaltojen: vuonna 1945 Suomen syntyneisyysluku oli jo noussut 25.5 promilleen kun Amerikan oli ainoastaan 20.4 promillea.

Mutta ehkä selvempi kuva 1950-luvulla vallinneesta vastakkaisesta kehityksestä saadaan kuviosta 2. Siinä syntyneiden lukumäärä kuvataan prosentteina syntyneiden lukumäärästä vuonna 1950 erikseen kummassakin maassa ja erikseen kunakin vuotena vuodesta 1945 vuoteen 1961.

Syntymätapausten absoluuttista lukumäärää on tarkasteltava väestönlisäyksenä, joka merkitsee uusia taloudellisia vaatimuksia ja myöskin uutta työvoimaa. Absoluuttiset lukumäärät ovat sentähden kiinnostavampia kuin suhdeluvut. Lyhyempinä ajanjaksoina syntymätapausten lukumäärä ja yleinen syntyneisyysluku vaihtelevat luonnollisesti samaan suuntaan kuten taulukossa 2 olevat tiedot osoittavat. Mutta pitempinä ajanjaksoina, varsinkin silloin kun syntyvyys on suuri kuten Yhdysvalloissa, suuri vuotuinen väkiluvun lisäys on omiaan alentamaan yleistä syntyneisyyslukua. Ilmaisemalla syntymätapausten vuotuinen määrä prosentteina vuoden 1950 syntyneiden määrästä voidaan korostaa vuotuisen väestönlisäyksen suuruutta ja tehdä mahdolliseksi vertailu Suomen ja Yhdysvaltain välillä, mikä muutoin olisi vaikeaa suurista absoluuttisista eroista johtuen (ks. taulua 2).

Kuvion 2 tutkiminen paljastaa radikaalisen vastakohdan syntyneisyysluvuissa vuoden 1950 jälkeen. Jokaisena vuotena Suomessa on ollut vähemmän syntymätapauksia kuin vuonna 1950 ja Yhdysvalloissa taas enemmän kuin kyseisenä perusvuotena. Lisäksi voidaan havaita huomattava lasku Suomessa ja nousu Yhdysvalloissa aina vuoteen 1957 asti kuten havaitaan kuviosta 2, missä viivat menevät eri suuntiin $100 \%$ osoittavan perusviivan ylä- ja alapuolelle. Viime vuosina kuitenkin syntymätapausten lukumäärät ovat alkaneet tasoittua niin, että Suomessa on nyt noin $16 \%$ vähemmän elävänä syntyneitä vuosittain kuin 1950 ja Yhdysvalloissa vastaavasti $18 \%$ enemmän. Kuvion 2 tiedot vuosilta $1945-50$ vahvistavat edellä tehdyt johtopäätökset ja osoittavat, että syntyvyys Suomessa nousi varhemmin ja tämä nousu oli jossain määrin voimakkaampi kuin Yhdysvalloissa. 
Kuvio 2. Syntymätapausten lukumäärä Suomessa ja Yhdysvalloissa v. 1945-61 prosentteina v:n 1950 syntymätapauksista. Fig. 2. Numbers of Births 1945-61 as Percentage of 1950 Births, Finland and the United States.

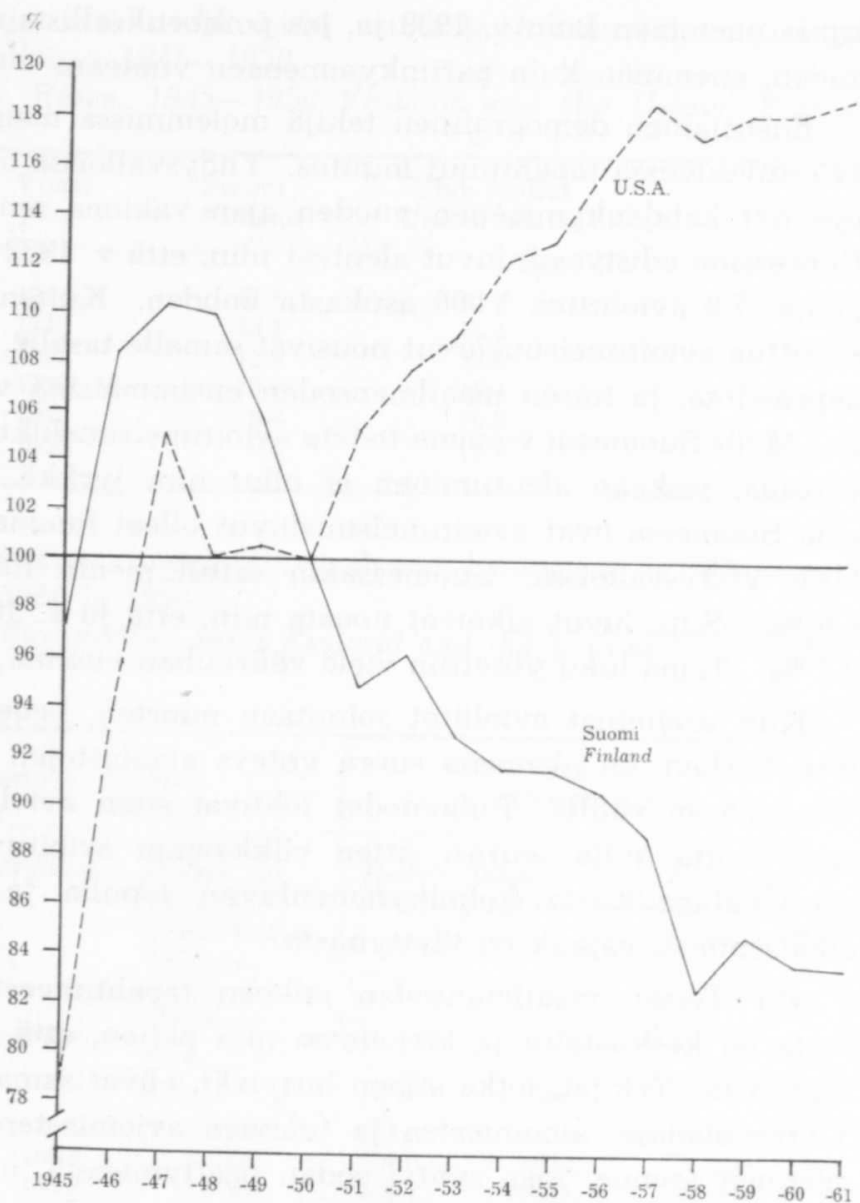

\section{Kehitykseen johtaneista tekijöistä}

Yrittäessämme tulkita syntyvyyden kehityssuuntaa, jota edellä on kuvailtu, käsittelemme sosiokulttuurisia tekijöitä ja eräitä väestöllisiä perustekijöitä sekä päätämme esityksen eräisiin huomautuksiin, jotka koskevat perhe-elämän arvonmuutoksia. Käsittelemme tässä yhteydessä molempia maita samanaikaisesti.

(1) Syntyvyyden kasvu pulavuosilta 1930-luvulla toisen maailmansodan vuosiin asti voi johtua suurimmaksi osaksi siitä, että ihmiset olivat halukkaampia avioitumaan, ottamaan vastatakseen lasten kasvatuksesta, kun taloudelliset olot tulivat helpommiksi, kun oli enemmän työpaikkoja ja kun palkat nousivat. Maailmantilanteessa tapahtunut jännityksen nousu ja sotakokemus nostatti kansallista moraalia ja siten rohkaisi perheen muodostusta ja lasten kasvatusta. Näin syntyvyys nousi Yhdysvalloissa sotavuosinakin aina vuoteen 1943 asti. Myös Suomessa syntyi vuonna 1944 
lapsia enemmän kuin v. 1939 ja, jos poikkeuksellista v. 1941 ei oteta huomioon, enemmän kuin pariinkymmeneen vuoteen.

Ensisijainen demografinen tekijä molemmissa maissa oli tällä kaudella avioituvuudessa tapahtunut muutos. Yhdysvalloissa oli avioituneisuusluku pysynyt kahdenkymmenen vuoden ajan vakiona aina vuoteen 1929 asti. Depression edistyessä luvut alenivat niin, että v. 1932 oli saavutettu aallon pohja: 7.9 avioliittoa 1000 asukasta kohden. Kuitenkin jo parin vuoden kuluttua avioituneisuusluvut nousivat samalle tasolle, jolla ne olivat ennen depressiota, ja toisen maailmansodan ensimmäisinä vuosina jopa ylittivät ne. Myös Suomessa voimme todeta avioituneisuuslukujen alentuneen pulavuosina, joskaan alentuminen ei ollut niin jyrkkä kuin Yhdysvalloissa, sillä Suomessa ovat avioituneisuusluvut olleet huomattavasti alhaisemmat kuin Yhdysvalloissa. Suomessakin sattui pienin luku vuodelle 1932 $6.6 \%$. Siitä luvut alkoivat nousta niin, että jo v. 1938 saavutettiin luku $9.2 \%$. Tämä luku ylitettiin vielä välirauhan vuonna 1941 .

Kun useimmat avioliitot solmitaan nuorten, hedelmällisessä iässä olevien kesken, on olemassa suora yhteys avioliittojen ja syntymätapausten lukumäärän välillä. Pulavuodet johtivat siten avioliittojen lykkääntymiseen, mutta niitä seurasi sitten vilkkaampi avioituvuus. Vastaavasti osa syntymätapauksista kolmikymmenluvun lopulla ja sotavuosina edustaa aikaisemman vajauksen täyttymistä.

(2) Toisen maailmansodan jälkeen tapahtuneesta syntyvyyden noususta on keskusteltu ja kirjoitettu niin paljon, että tarvitaan vain vähän lisättävää. Tekijät, jotka siihen liittyivät, olivat samat niin Suomessa kuin Yhdysvalloissa: aviomiesten ja tulevien aviomiesten kotiuttaminen, optimistinen asenne, joka syntyi sodan päättymisestä, uusien normien asteittainen leviäminen, normien, jotka pyrkivät rohkaisemaan varhaista avioliittoa ja yhä harvemmin esitetty vaatimus, että nuorten miesten tulisi odottaa kunnes pystyisivät itse elättämään perheensä. Kaikki nämä tekijät pyrkivät rohkaisemaan avioliiton solmimista ja varhaisempaa lasten synnyttämistä. Avioituneisuusluvut sodanjälkeisiltä vuosilta nähdään taulusta 3. Ne osoittavat selvästi, kuinka nopeasti kummassakin maassa sodan päätyttyä uudet perheet alkoivat muodostua. Korkeimmat suhdeluvut ovat vuonna 1946. Ei siis ole lainkaan ihme, että v. 1947 havaittiin vastaavanlainen nousu syntyneisyysluvuissa.

(3) Edellä jo on todettu syntyneisyydessä tapahtuneen kehityksen käyneen eri suuntiin 1950-luvulla Suomessa ja Yhdysvalloissa. Yhdysvalloissa tämä ilmiö oli odottamaton, koska sodanjälkeinen nousu hedelmällisyydessä on useimmissa maissa ollut lyhytaikainen. Se on kiinnostavaa, koska sen demografisen luonteen analysoiminen on pakottanut meidät tekemään johtopäätöksen, että se voidaan ymmärtää seurauksena niistä arvojen ja normien muutoksista, jotka määräävät amerikkalaisen perhe-elämän luonteen. 
Taulu 3. Solmittuja avioliittoja 1000 asukasta kohden Suomessa ja Yhdysvalloissa $1945-1950$.

T a ble 3. Marriage Rates, 1945-1950 Finland and the United States.

\begin{tabular}{lcc}
\hline $\begin{array}{l}\text { Vuosi } \\
\text { Year }\end{array}$ & $\begin{array}{l}\text { Suomi } \\
\text { Finland }\end{array}$ & $\begin{array}{c}\text { Yhdysvallat } \\
\text { United States }\end{array}$ \\
\hline 1945 & 11.8 & 12.2 \\
1946 & 13.1 & 16.4 \\
1947 & 11.3 & 13.9 \\
1948 & 10.0 & 12.4 \\
1949 & 8.8 & 10.6 \\
1950 & 8.5 & 11.1 \\
\hline
\end{tabular}

T a u lu 4. Ikäryhmittäiset hedelmällisyysluvut Suomessa ja Yhdysvalloissa v. 1950 ja 1959.

T a ble 4. Age-specific fertility rates Finland and the United States, 1950 and 1959.

\begin{tabular}{|c|c|c|c|c|c|c|}
\hline \multirow[b]{2}{*}{$\begin{array}{l}\text { Ikäryhmä } \\
\text { Age Group }\end{array}$} & \multicolumn{3}{|c|}{ Suomi - Finland } & \multicolumn{3}{|c|}{$\begin{array}{l}\text { Yhdysvallat - } \\
\text { United States }\end{array}$} \\
\hline & $\begin{array}{l}\text { Hedelmä } \\
\text { Fertility }\end{array}$ & $\begin{array}{l}\text { yysluku } \\
\text { te }\end{array}$ & $\begin{array}{l}\text { Lisäys tai } \\
\text { vähennys } \\
\text { prosentteina } \\
\text { Percent } \\
\text { Increase or } \\
\text { Decrease }\end{array}$ & $\begin{array}{l}\text { Hedelm: } \\
\text { Fertility }\end{array}$ & $\begin{array}{l}\text { Illisyysluku } \\
\text { Rate }\end{array}$ & $\begin{array}{l}\text { Lisäys tai } \\
\text { vähennys } \\
\text { prosentteina } \\
\text { Percent } \\
\text { Increase or } \\
\text { Decrease }\end{array}$ \\
\hline & 1950 & 1959 & & 1950 & 1959 & \\
\hline $\begin{array}{l}15-19 \\
20-24 \\
25-29 \\
30-34 \\
35-39 \\
40-44\end{array}$ & $\begin{array}{r}27.1 \\
154.6 \\
175.5 \\
136.0 \\
93.1 \\
40.4\end{array}$ & $\begin{array}{r}29.5 \\
160.2 \\
158.2 \\
106.6 \\
65.7 \\
26.1\end{array}$ & $\begin{array}{l}+8.9 \\
+\quad 3.6 \\
-9.9 \\
-21.6 \\
-29.4 \\
-35.4\end{array}$ & \begin{tabular}{r|}
81.6 \\
196.6 \\
166.1 \\
103.7 \\
52.9 \\
15.1
\end{tabular} & $\begin{array}{r}90.9 \\
256.4 \\
200.6 \\
116.1 \\
58.5 \\
15.7\end{array}$ & $\begin{array}{l}+11.4 \\
+30.6 \\
+20.8 \\
+12.0 \\
+10.6 \\
+\quad 4.0\end{array}$ \\
\hline $15-44$ & 106.1 & 89.6 & -15.5 & 106.2 & 120.2 & +13.2 \\
\hline
\end{tabular}

Aloittaaksemme demografisista tekijöistä on ensiksi kiinnitettävä huomio vuosien 1950 ja 1960 välillä ikärakenteessa tapahtuneeseen muutokseen. Yhdysvalloissa aleni tällöin 20-29-vuotiaiden osuus $15.7 \%$ :sta $12.1 \%$ :iin. Näin huomattava $-23 \%$ - aleneminen hedelmällisimmässä iässä olevien kohdalla olisi aiheuttanut epäilemättä alenemista myös syntyvyydessä, jolleivät muut tekijät olisi sitä kompensoineet. Näinhän itse asiassa Suomessa tapahtuikin, vaikka hedelmällisimmässä iässä olevien osuus aleni vain $14 \%$.

Ne tekijät, jotka kompensoivat Yhdysvalloissa 1930-luvulla tapahtuneen ikäluokkien vajauksen, joka muutoin olisi 1950-luvulla johtanut syntyvyyden alenemiseen, olivat avioliiton solmimisiän aleneminen ja kaikissa ikä- 
ryhmissä tapahtunut hedelmällisyyden nousu. Kun ensimmäisen avioliiton solmimisikä (mediaani) naisilla v. 1950 oli 22.5 vuotta, se vuonna 1960 oli alentunut 20.2 vuoteen. Näin ollen suurempi osuus $20-29$-vuotiaista oli vuosikymmenen lopulla naimisissa kuin sen alussa. Tämä vaikutti suoranaisesti syntyvyyteen kuten 20-24-vuotiaiden hedelmällisyysluvun kasvu 34 prosentilla vuodesta 1950 vuoteen 1959 osoittaa (taulu 4). Mutta ikäryhmittäiset hedelmällisyysluvut nousivat myös kaikissa muissa ikäryhmissä. Tämä yleinen ilmiö ei ainoastaan kompensoinut sitä, että väestöstä oli pienempi osuus hedelmällisessä iässä, vaan korotti myös 15-44vuotiaiden hedelmällisyyslukua 13.2 prosentilla.

Sosiokulttuuriset tekijät, jotka liittyvät tähän jatkuvaan ja yhä kohoavaan syntyvyyteen, ovat samat, jotka on huomattu aikaisemmilta kausilta: asenteet, jotka suosivat avioliittoa ja lapsia, hyvät taloudelliset olot, jotka ilmenevät täystyöllisyytenä ja kohoavana elintasona. Syntyvyyden jatkuva kohoaminen koko 1950-luvun ajan voidaan selittää johtuvaksi arvojen muutoksista, jotka suosivat varhaista avioliittoa ja perheitä, joissa on useampia lapsia kuin kaksi tai kolme. Taulu 5 antaa aiheen tällaisen johtopäätöksen tekemiseksi. Siitä havaitaan, että molemmissa maissa ensimmäiset, toiset ja kolmannet lapset, joiden kohdalla tapahtui syntyneisyysluvuissa voimakas lisääntyminen vuoteen 1947 asti, suurimmaksi osaksi selittävät korkean syntyvyyden 1940-luvun lopulla. Suomessa järjestysluvultaan 1.-3. lapsen kohdalla suurimmat suhdeluvut saavutettiin juuri näinä vuosina. Sitä vastoin Yhdysvalloissa ainoastaan 1. lapsen kohdalla suurin suhdeluku on v. 1947. Muut, erityisesti kolmannet ja sen jälkeiset lapset ovat lisääntyneet vasta 1950-luvun lopulla ja kompensoineet ensimmäisten ja toisten lasten vähennyksen. Suomessakin voidaan havaita tämänsuuntaisen kehityksen itu - 4. ja 5. lapset ovat suhdeluvultaan suurimmat v. 1952 - mutta se ei ole jaksanut voimistua samanlaiseksi aalloksi kuin Yhdysvalloissa. Näin on selvästi osoitettu, että Yhdysvalloissa nuoret aikuiset, jotka perustivat perheen toisen maailmansodan aikana ja sen jälkeen, jatkuvasti koko 1950-luvun ajan laajensivat sitä. Samanaikaisesti heidän nuoremmat sisarensa ja veljensä menivät naimisiin aikaisemmin ja saivat enemmän lapsia nuorempana.

Näin ollen muodostui Yhdysvalloissa 1950-luvulla uusi perhemalli, jolle on tunnusomaista aikainen avioituminen, varhaisempi lasten saanti ja suurempi lapsijoukko ainakin avioliiton varhaisemmassa vaiheessa. Jatkuuko tällainen kehitys vielä 1960-luvulla on avoin kysymys. Käsityksemme kuitenkin on, että syntyvyyden ja familismin huippu Yhdysvalloissa on jo saavutettu, niin että tämän kymmenluvun viimeisinä vuosina on odotettavissa paluu pienperheisiin. Tällöin näet sodan jälkeen syntyneet lapset ovat kasvaneet aikuisiksi ja kokeneet nopeasti kasvaneiden suurperheiden haitat ollen ehkä itse halukkaita omalla kohdallaan muodostamaan pienemmän perheen. Kuitenkin vielä tärkeämpi seikka saattaa olla se, että 
Ta ulu 5. Syntyneisyysluvut synnytyksen järjestysluvun mukaan Suomessa ja Yhdysvalloissa 1940-1959 (tuhatta 15-44-vuotiasta naista kohden).

Table 5. Birth rates by order of birth Finland and the United States selected years, 1940-1959 (rates per 1000 females 15-44).

$$
\text { Suomi - Finland }
$$

Järjestysluku - Birth order

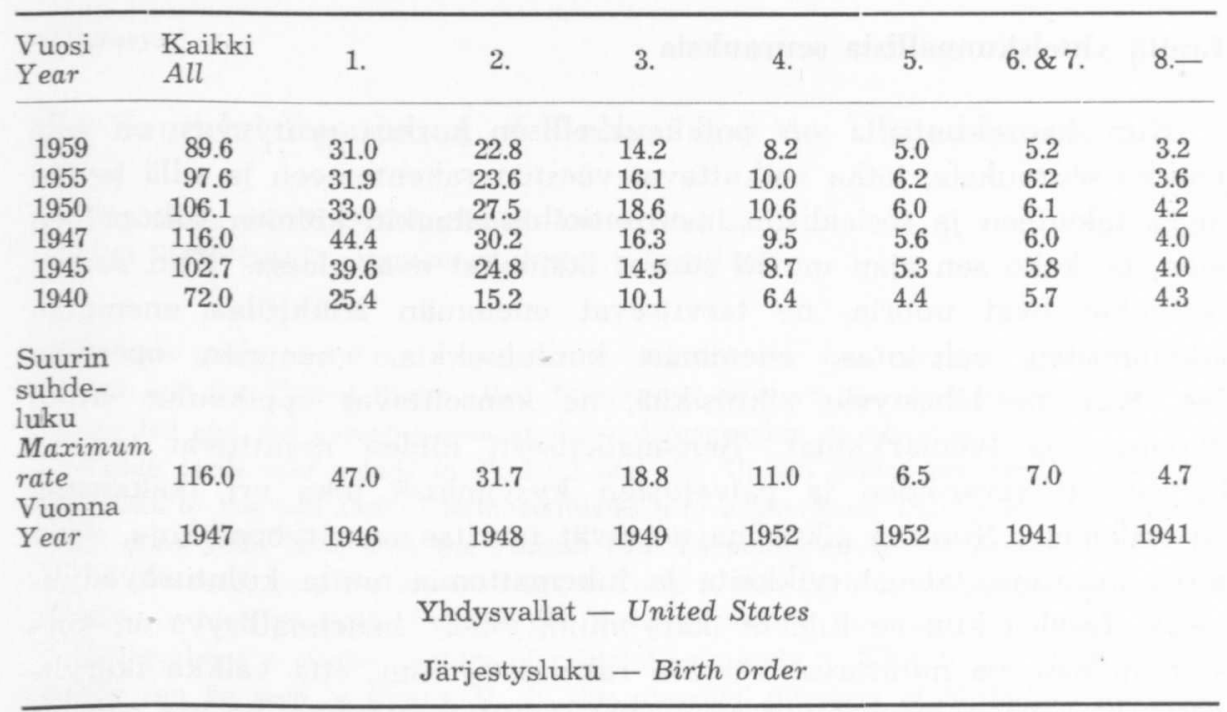

\begin{tabular}{|c|c|c|c|c|c|c|c|c|}
\hline $\begin{array}{l}\text { Vuosi } \\
\text { Year }\end{array}$ & $\begin{array}{l}\text { Kaikki } \\
\text { All }\end{array}$ & 1. & 2. & 3. & 4. & 5. & 6. \& 7 . & 8.- \\
\hline 1959 & 120.2 & 31.7 & 30.1 & 23.3 & 14.7 & 8.3 & 7.6 & 4.4 \\
\hline 1955 & 118.0 & 32.7 & 31.7 & 23.0 & 13.3 & 7.2 & 6.3 & 3.8 \\
\hline 1950 & 106.2 & 33.3 & 32.1 & 18.4 & 9.2 & 4.8 & 4.7 & 3.6 \\
\hline 1947 & 113.3 & 46.7 & 30.3 & 15.6 & 7.9 & 4.5 & 4.6 & 3.7 \\
\hline 1945 & 85.9 & 28.9 & 22.9 & 13.4 & 7.5 & 4.5 & 4.8 & 4.0 \\
\hline 1940 & 79.9 & 29.3 & 20.2 & 10.9 & 6.4 & 4.1 & 4.8 & 4.3 \\
\hline \multicolumn{9}{|l|}{$\begin{array}{l}\text { Suurin } \\
\text { suhde- } \\
\text { luku }\end{array}$} \\
\hline $\begin{array}{l}\text { Maximum } \\
\text { rate } \\
\text { Vuonna }\end{array}$ & 122.7 & 46.7 & $\begin{array}{l}32.5 \\
1951\end{array}$ & 23.9 & 14.7 & 8.3 & 7.6 & 4.4 \\
\hline Year & 1957 & 1947 & 1952 & 1957 & 1959 & 1959 & 1959 & 1959 \\
\hline
\end{tabular}

he ovat suuren sukupolven jäseniä, jolle taloudellinen kilpailu voi olla vaikea, sillä se täyttää työpaikat samanaikaisesti, kun automaatio vähentää työntekijäin tarvetta monilla aloilla.

Syntyvyyden asteittainen aleneminen 1950-luvun Suomessa liittyy arvattavasti epäedullisempiin taloudellisiin oloihin ja avioliitto- ja perhenormeihin, jotka suosivat myöhempää avioliiton solmimista ja pienempää 
perhettä kuin Yhdysvalloissa. Naisten osallistuminen ansiotyöhön, mikä osittain on seuraus nopeasta teollistumisesta, heijastaa erilaisia määritelmiä naisen yhteiskunnallisesta roolista korostaen ehkä suurempaa tasa-arvoisuutta ja ammattipätevyyttä. Vaikka Yhdysvalloissa naisten työhön osallistuminen nousee, naisten ammatit eivät ole sosiaalisesti yhtä hyväksyttyjä kuin Suomessa.

\section{Eräitä yhteiskunnallisia seurauksia}

Kun kansakunnalla on poikkeuksellisen korkea syntyvyys, on sillä joukko seurauksia, jotka vaikuttavat väestön rakenteeseen ja sillä tavoin myös talouteen ja sosiaalisiin instituutioihin ainakin kolmen sukupolven ajan, ts. koko sen ajan minkä suuret ikäluokat ovat elossa. Kun suuret ikäluokat ovat nuoria, ne tarvitsevat enemmän leikkitilaa, enemmän aikaihmisten valvontaa, enemmän koululuokkia, enemmän opettajia jne. Kun ne lähestyvät aikuisikää, ne kansoittavat oppikoulut sitten yliopistot ja työmarkkinat. Samanaikaisesti niiden muuttuvat tarpeet heijastuvat tavaroiden ja palvelusten kysynnässä, joka eri ikäkausina on erilainen. Nuorina aikuisina ne eivät tarvitse vain työpaikkoja, vaan myös asuntoja, taloustarvikkeita ja lukemattomia muita kulutushyödykkeitä. Lisäksi kun ne tulevat ikäryhmiin, jolloin hedelmällisyys on korkeimmillaan, ne muuttavat väestön rakennetta niin, että vaikka ikäryhmittäiset hedelmällisyysluvut pysyisivät muuttumattomina, ne itse tulevat uuden suuren ikäkohortin vanhemmiksi ja ulottavat vaikutuksensa siten ohi oman elinaikansa. Tämä voi tapahtua sekä Suomessa että Yhdysvalloissa 1960-luvun lopulla.*

Ikärakenteen muutoksilla voi myös olla poliittisia seurauksia, koska jonkin aikaa suuri joukko ihmisiä on nuoria ja nuoremmat voivat olla vastaanottavaisempia muutoksille. Kun aikaa kuluu enemmän, suuret ikäluokat jatkuvasti asettavat omia vaatimuksiaan eri ikäkausina tarvikkeille, hyödykkeille ja palveluksille. Lopulta ne saavuttavat eläkeiän (65 vuotta), joka alkaa vuonna 2010 ja aiheuttavat äkkiä suuremman elatusrasituksen yhteiskunnalle. Suurten ikäluokkien viimeinen panos erikoiskysynnässä ilmenee hautauspalvelusten kysyntänä, joka alkaa ensi vuosisadan toisena vuosikymmenenä.

Tämä merkitsee sitä, että yhteiskunnan, jossa suuret ikäluokat kasvavat, täytyy kohdata kaikki ne ongelmat ja sen tulisi käyttää kaikki tilai-

* Näistä syistä ja vaikka Amerikan avioliitto- ja perhenormeissa tapahtuisi uudelleen muotoutumista, josta on ollut aikaisemmin puhe, 1960-luvun lopulla on täysin mahdollista että yleinen hedelmällisyys USA:ssa voi pysyä yhtä sưurena tai jopa noustakin, koska sodanjälkeisten lasten vanheneminen on lisännyt hedelmällisimmässä iässä olevien lukumäärää. 
suudet hyväkseen, jotka syntyvät siitä kun tavallista suurempi ikäryhmä on olemassa. Onneksi väestön muuttuva ikärakenne voidaan etukäteen laskea melko tarkasti ainakin kymmeneksi vuodeksi, niin että ne, jotka harjoittavat sosiaalipolitiikkaa, voivat ottaa huomioon demografisen kehityksen päätöksiä tehdessään.

\title{
Summary:
}

\section{The Youthful Population of Finland and the United States}

\author{
By FRANK L. SWEETSER * (Boston University) and \\ PAAVO PIEPPONEN (Population Research Institute)
}

In this study, we have attempted to describe the rise of large age groups in Finland and the United States, the differences between the two nations, and the reasons for and the consequences of these demographic developments.

Crude birth rate trends in Finland and the United States are similar from the late 1930 's to the late 1940 's. Both countries also experienced their highest birth rate in the same year, 1947, with the Finnish rate 1.4 points above the American. It may also be observed, from the annual rates in Table 2, that the Finnish population reached a relatively high number of births per thousand sooner than did the United States.

But perhaps a clearer picture of contrasting trends in Finnish and United States fertility can be seen in Figure II. In this diagram, numbers of births are described as a percent of the number of births in 1950 in each of the two countries for each year from 1945 to 1961.

Study of Chart II reveals the radical contrast between the two countries in relative numbers of births since 1950. In every subsequent year Finland had fewer births than in that base-year. There was a marked trend downward (for Finland) and upward (for the United States) until about 1957, but in the most recent years plotted, numbers of births have tended to level off, with about 16 per cent fe wer births annually in Finland than in 1950, and about 18 percent more births annualiy in the United States than in 1950.

In interpreting the fertility trend, discussion may conveniently be organized to consider three series of events: (1) the rise in fertility from the 1930's to the end of World War II; (2) the baby-boom of the immediate post-war years; (3) the continuing - even rising - level of United States fertility during the 1950's.

(1) The increase in rates and numbers born from the depression years of the 1930 's to the end of World War II may be attributed largely to the changing attitudes and behavior of potential parents who became more willing (or eager) to marry, and less reluctant to undertake child-rearing as economic condition eased. With the practice of voluntary birth control wide-spread in both countries, changing parental value-orientations have become the major factor influencing the level of fertility. The rise in world tensions, and the experience of war, acted to increase national morale and thus encourage family formation and child-rearing.

* Professor Sweetser was a Fulbright Lecturer at the University of Helsinki in $1962-63$. 
The primary demographic factor in this period is the changing marriage rate. The depression led to a postponement of marriages, but was followed by higher marriage and birth rates which were in part a consequence of making up for earlier deficits.

(2) The post-World War II baby-boom involved many of the same factors in Finland and the United States as those in many other countries. Demobilization and the return of husbands and husbands-to-be to their homes, pervasive attitudes of optimism arising from the termination of the war, the gradual diffusion of new norms based on war-time practices, all tended to encourage both marriage and earlier childbearing. Marriage rates for the post-war years are shown in Table 3, and dramatically reveal how rapidly new families were formed in both countries. It is no wonder that there was a corresponding dramatic rise in the birth rate in 1947.

(3) The continuing - and rising - level of United States fertility during the 1950 's is an interesting - and an unexpected - phenomenon. It is unexpected, because while post-war fertility increases are commonly observed, they are usually of short duration, as in Finland and in most of the urban-industrial nations of the world after World War II. It is interesting, because analysis of its demographic character has forced us to conclude that it can only be understood as a consequence of a fundamental shift in the values and norms which determine the character of family life for Americans.

To begin with the demographic factors, we must note an important shift in the age structure of the United States population between 1950 and 1960 , the drop in the percent of total population age 20-29 years from 15.7 to 12.1 (See Table 1 and Figure 1). This 23 percent decline in proportions in the most highly fertile ages would have produced a marked decline in birth rates had it not been compensated for by other factors. Demographically, the operative sother factors, were a decline in the age at first marriage, and a persistent rise in age-specific birth rates (Table 4). Median age at first marriage (brides) was 22.5 years in 1950, 20.4 years in 1955, and 20.2 years in 1959 for reporting states.

Socio-cultural factors associated with this rising fertility are like those noted for the previous periods: attitudes favoring marriage and child-bearing and favorable economic conditions including full employment and rising real wages. But its continuance can only be accounted for by a fundamental shift in American values favoring not only early marriage, but families of several children rather than only two or three. Table 5 summarizes the demographic evidence for this conclusion, by expressing birth rates by birth-order for selected years.

The termination of the period of high fertility in Finland has been shown to be associated with difficult economic conditions and the development of a pattern of marriage and family norms favoring later marriage and fewer children than in the United States. Large scale participation of Finnish women in the labor force, in part a consequence of rapid urbanization and a less affluent economy than the American, also reflects different cultural definitions of women's societal role, emphasizing, perhaps, greater equality, and the greater validity of careers of women. Even though female labor participation in the United States is rising, careers for women there do not have the same social acceptance as in Finland. Finnish women marry later and bear fewer children than women in the United States, largely because the special circumstances which gave rise to a new pattern of family norms in America during the 1950 's were not operating in Finland, while some counter-pressures were operating to reduce Finnish fertility to the levels of the late 1930 's.

When a nation experiences exceptionally high fertility for a number of years a series of consequences are set in train which will affect the population structure, and 
hence the economy and the social institutions of that nation for at least three generations - that is, for the life-time of the large age groups. Whether planning is easier with the large age groups concentrated in the span of a few years, so that they comprise a bulge in numbers and proportions in successively later ages as time passes (the Finnish situation); or with the large age cohorts following each other in routine succession for fifteen years or more (the American case), is an issue beyond the scope of this paper. Fortunately, the shifting patterns of population can be projected into the future with reasonable accuracy, at least for a decade or so, permitting those who determine social policy to take realistic account of the demographically obvious shape of things to come in their deliberations. 